Abstractacta Iranica

Revue bibliographique pour le domaine irano-aryen

Volume 40-41 | 2019

Comptes rendus des publications de 2017-2018

\title{
Oded Lipschits et al. What Are the Stones Whispering? Ramat Rahel: 3000 Years of Forgotten History
}

\section{Astrid Nunn}

\section{(2) OpenEdition}

1 Journals

\section{Édition électronique}

URL : http://journals.openedition.org/abstractairanica/50002

DOI : 10.4000/abstractairanica.50002

ISBN : 1961-960X

ISSN : 1961-960X

Éditeur :

CNRS (UMR 7528 Mondes iraniens et indiens), Éditions de l'IFRI

Référence électronique

Astrid Nunn, « Oded Lipschits et al. What Are the Stones Whispering? Ramat Rahel: 3000 Years of

Forgotten History», Abstracta Iranica [En ligne], Volume 40-41 | 2019, document 76, mis en ligne le 30 octobre 2019, consulté le 21 avril 2021. URL : http://journals.openedition.org/abstractairanica/50002 ; DOI : https://doi.org/10.4000/abstractairanica.50002

Ce document a été généré automatiquement le 21 avril 2021.

Tous droits réservés 


\title{
Oded Lipschits et al. What Are the Stones Whispering? Ramat Rahel: 3000 Years of Forgotten History
}

\author{
Astrid Nunn
}

\section{RÉFÉRENCE}

Oded Lipschits et al. What Are the Stones Whispering? Ramat Rahel: 3000 Years of Forgotten History. Winona Lake : Eisenbrauns, 2017, 183 p., nombreuses illustrations

1 Les 3000 ans d'histoire de ce site, situé au sud de Jérusalem, couvre la période du Fer II à nos jours. La période achéménide correspond à la phase III et est traitée dans la Section II (p. 95-112). Un grand «palais royal » accompagné d'un «jardin royal» fut construit à fin du VIIIème $s$. et réaménagé plus tard. Sa troisième phase est achéménide. Le jardin était alimenté en eau par un système sophistiqué de bassins et de canaux. 302 estampes yehud indiquent clairement l'importance administrative de ce palais, dont la fonction était de collecter les taxes, payées sous forme de vin et d'huile. Un puits était empli de déchets et de tessons de céramique. Pour la première fois, il fut possible de reconstituer le type de jarre estampillée du sceau yehud. Les analyses ont révélé que ces jarres contenaient de l'hydromel. La végétation des jardins était variée : vigne, figuier, peuplier, saule, nymphea et myrte étaient locaux. Quant aux arbres importés, il y avait des citronniers, venus d'Inde via la Perse, des noyers de Perse, des cèdres du Liban et des bouleaux.

2 Après avoir existé environ 500 ans ce complexe architectural fut détruit au second siècle avant J.-C., ne laissant plus aucune trace et transformant Ramat Rahel en un site rural. 


\section{AUTEURS}

\section{ASTRID NUNN}

Université de Munich 